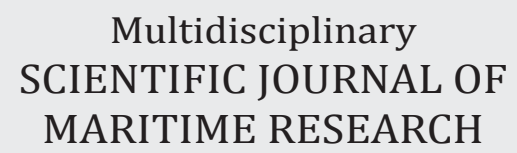

Multidisciplinary

MARITIME RESEARCH

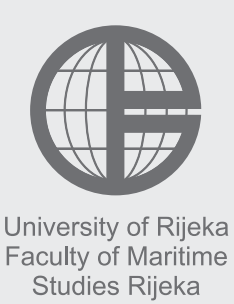

Multidisciplinarni

znanstveni časopis

POMORSTVO

\title{
Change in Steam Generators Main and Auxiliary Energy Flow Streams During the Load Increase of LNG Carrier Steam Propulsion System
}

\author{
Vedran Mrzljak, Jasna Prpić-Oršić, Tomislav Senčić \\ University of Rijeka, Faculty of Engineering, Vukovarska 58, 51000 Rijeka, e-mail: vedran.mrzljak@riteh.hr; jasna.prpic-orsic@riteh.hr; \\ tomislav.sencic@riteh.hr
}

\section{ABSTRACT}

In this paper is presented an analysis of main and auxiliary steam energy flow streams from steam generators during the increase in steam system load at conventional LNG carrier. During the steam system load increase was presented differences in steam pressure and temperature between main and auxiliary steam flow streams. Energy power of the auxiliary flow stream is higher than energy power of the main flow stream only at the lowest steam system loads after which main flow stream takes over primacy at middle and high steam system loads. Cumulative auxiliary energy flow stream was divided on energy flow streams to each auxiliary device and energy power consumption of each auxiliary device was also investigated throughout number steam system loads. Analysis of steam production from marine steam generators presented in this paper provides insight into the operation dynamics of the entire steam propulsion system.

\section{ARTICLE INFO}

Original scientific paper Received 19 March 2018

Accepted 7 June 2018

\section{Key words:}

LNG carrier

Steam propulsion

Load variation

Energy flow

Steam generator

\begin{tabular}{|c|c|c|c|}
\hline \multicolumn{4}{|c|}{ NOMENCLATURE } \\
\hline \multicolumn{2}{|c|}{ Abbreviations: } & \multicolumn{2}{|c|}{ Subscripts: } \\
\hline \multirow{2}{*}{ DWT } & \multirow{2}{*}{$\begin{array}{l}\text { Deadweight } \\
\text { Tonnage }\end{array}$} & $\mathrm{AD}$ & Auxiliary device \\
\hline & & $\mathrm{AH}$ & Air heaters \\
\hline LNG & Liquefied Natural Gas & AUX & Auxiliary \\
\hline \multicolumn{2}{|c|}{ Latin Symbols: } & $\mathrm{CU}$ & Cumulative \\
\hline \multirow{2}{*}{$\dot{E}$} & \multirow{2}{*}{$\begin{array}{l}\text { stream flow power, } \\
\mathrm{kW}\end{array}$} & DEA & Deaerator \\
\hline & & DES & Desuperheater \\
\hline \multirow{2}{*}{$h$} & \multirow{2}{*}{$\begin{array}{l}\text { specific enthalpy, } \\
\mathrm{kJ} / \mathrm{kg}\end{array}$} & DU & Dump \\
\hline & & en & energy \\
\hline$\dot{m}$ & mass flow rate, $\mathrm{kg} / \mathrm{h}$ & IN & inlet (input) \\
\hline$P$ & power, kW & MA & Main \\
\hline$\dot{Q}$ & heat transfer, kW & OUT & outlet (output) \\
\hline$S H$ & share, $\%$ & SS & Splash steam \\
\hline
\end{tabular}

\section{Introduction}

Internal combustion diesel engines in general (mostly slow speed diesel engines) have a leading role in ship propulsion nowadays $[1,2]$. The wide presence of diesel engines in ship propulsion enabled the development of different numerical models for investigation of their operating parameters $[3,4]$ and for optimization of their processes [5].

Steam propulsion is slightly present on ships, but is still the dominant propulsion of LNG (Liquefied Natural Gas) carriers [6] due to the specificity of their operation and the transported cargo. Any steam system as well as the steam propulsion system is very complex because it is assembled from a large number of components [7]. The marine steam propulsion system in comparison with any conventional land-based steam power system is much more dynamic in its operation.

The marine steam propulsion system consists of two steam generators [8] due to safety and reliable operation and two parallel operating turbo-generators [9] to ensure 
electricity supply at any time. Propulsion propeller (or more of them) drive is ensured with main propulsion turbine [10]. Steam after expansion in turbo-generators and main propulsion turbine goes to the main condenser [11] on liquefaction.

On water return channel to steam generators there are several devices which provide condensate and feed water heating. The first of such devices is evaporator (fresh water generator) [12]. The evaporator is a steam propulsion system component which is not required in conventional landbased steam power systems. After evaporator is usually located sealing steam condenser [13] and two or more feed water heaters $[14,15]$. Between feed water heaters is located deaerator [16] with its dual function - feed water heating and removal of gaseous components from feed water. The water return channel also consists of hot well [17] for collecting all the condensate from the steam propulsion system and desuperheater. Desuperheater is a heat exchanger which is used for steam cooling and preparation for the cargo and auxiliary systems heating [18]. General LNG carrier steam propulsion system scheme can be found in [9].

New systems for the propulsion of LNG carrier's are currently under development [19]. The main goal of such propulsion systems is greenhouse gas emissions reducing $[20,21]$. For these complex systems is necessary to provide the economic and profitability analysis [22] as well as operational risk assessment [23] with the aim to minimize possible harmful consequences.

In this paper were analyzed changes in main and auxiliary energy steam flow streams from steam generators in marine propulsion system of one conventional LNG carrier. Each energy flow stream was investigated during the steam propulsion system load increase (from the lowest to the highest system loads). It was compared differences in steam pressure and temperature between main and auxiliary steam energy flow streams. Cumulative auxiliary energy flow stream was divided on flow streams to each auxiliary device. Energy flow stream consumption of each auxiliary device was also investigated throughout all steam system loads.

\section{Description of Main and Auxiliary Energy Flow Streams in the Marine Steam Propulsion System}

A marine steam propulsion system which main and auxiliary energy flows were analyzed in this paper is mounted on conventional LNG carrier. The essential parts of this propulsion system are two mirror-oriented marine steam generators, one propulsion turbine (with two turbine cylinders), two identical turbo-generators for electrical power production and low power steam turbine with one Curtis stage for main feed water pump drive. Another characteristics and specifications of the analyzed LNG carrier are presented in Table 1.

Steam energy flow streams which exits both steam generators are divided to two different flows: main flow stream and auxiliary flow stream. Both flow streams from
Table 1 Analyzed LNG carrier main characteristics

\begin{tabular}{|l|l|}
\hline Dead weight tonnage & 84812 DWT \\
\hline Overall length & $288 \mathrm{~m}$ \\
\hline Max breadth & $44 \mathrm{~m}$ \\
\hline Design draft & $9.3 \mathrm{~m}$ \\
\hline Steam generators & $2 \times$ Mitsubishi MB-4E-KS \\
\hline Propulsion turbine & $\begin{array}{l}\text { Mitsubishi MS40-2 } \\
\text { (max. power 29420 kW) }\end{array}$ \\
\hline Turbo-generators & $\begin{array}{l}\text { 2 } \times \text { Shinko RGA 92-2 } \\
\text { (max. power 3850 kW each) }\end{array}$ \\
\hline MFP steam turbine & $\begin{array}{l}\text { Shinko DMG } 125-3 \\
\text { (max. power 570 kW) }\end{array}$ \\
\hline
\end{tabular}

steam generators are required and necessary for proper operation of analyzed marine steam propulsion system.

The main steam flow stream has a maximum pressure and temperature, which are dependable on steam generator specifications. Main steam flow stream in the observed propulsion system has a pressure of around $6 \mathrm{MPa}$ and a temperature of around $515{ }^{\circ} \mathrm{C}$. The main steam flow stream is used for operation of all steam turbines (main propulsion turbine, both turbo-generators and MFP steam turbine). Each steam turbine, regardless of turbine developed power, requires steam with maximum possible parameters (pressure and temperature) in any steam propulsion system.

The auxiliary steam flow stream is produced from the main flow stream. One part of produced main steam stream, which was not led to steam turbines, was sent back to the steam generators. That steam passes through steam drums and transferred one part of its heat content to feed water. Due to heat transfer, steam temperature significantly decreases while steam pressure also decreases, but not as significantly as the temperature. Such steam stream with lower temperature and pressure in comparison with main steam stream is called an auxiliary steam flow stream. After heat transfer is steam drums, auxiliary steam flow stream exits from steam generators. The auxiliary steam flow stream is used for the operation of auxiliary system devices which required steam with lower temperature and pressure in comparison with the main flow stream.

In the analyzed marine steam propulsion system, the auxiliary steam flow stream was used for the operation of five auxiliary devices: splash steam system, dump line, deaerator, desuperheater and steam generators air heaters, Fig. 1. Operation principle of each auxiliary device is explained as follows:

- Splash steam system: Splash steam system takes a small amount of auxiliary steam from steam generators for water preparation in order to use such prepared water for cooling purposes. Water prepared in the splash steam system is usually used for cooling of the main condenser or for cooling of a steam at the turbines outlet. In some operating regimes of marine steam propulsion system, steam which enters into the main condenser can still be superheated. Cooling of that superheated steam enables its liq- 


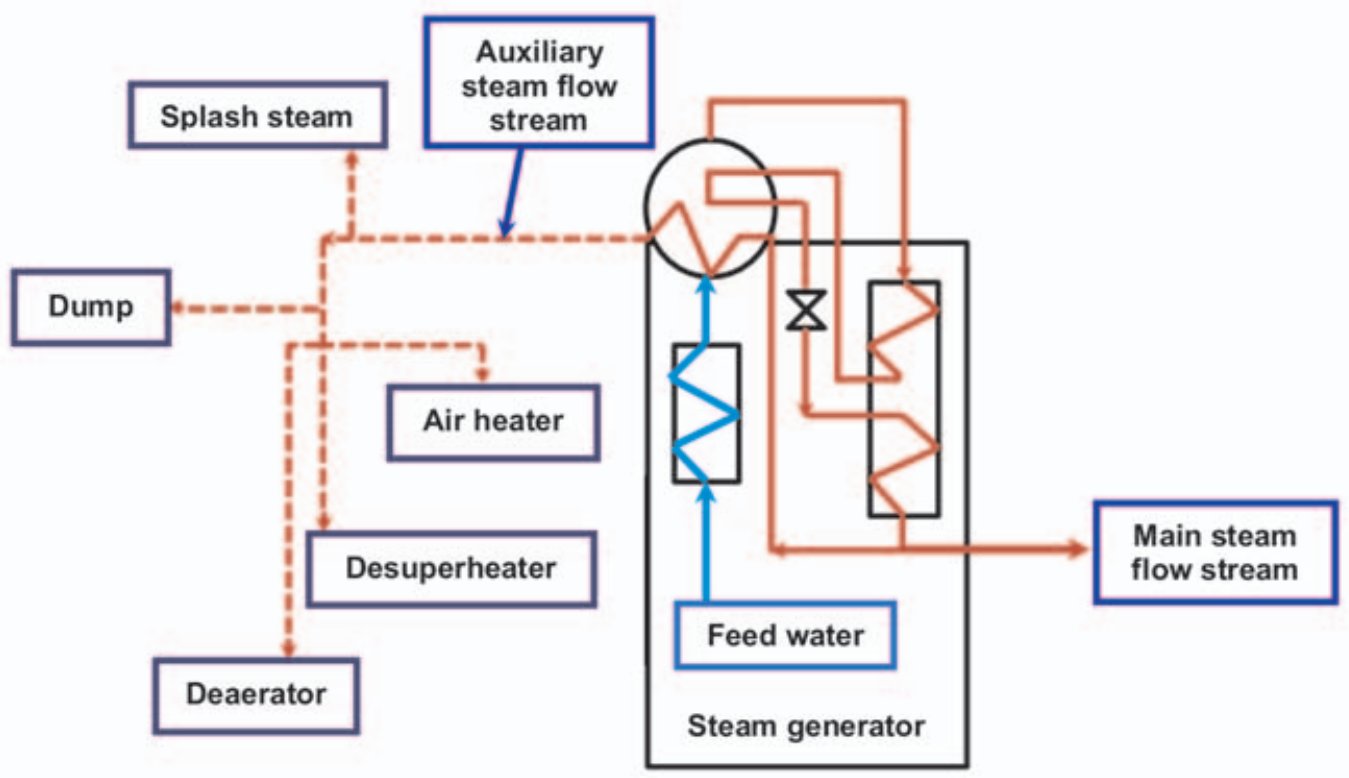

Figure 1 Scheme of one marine steam generator with main and auxiliary steam flow streams

uefaction. Water prepared in the splash steam system can also be used for the other cooling purposes in the steam propulsion system.

- Dump line: At low steam propulsion system loads, steam generators produce much more steam than an entire system requires. Steam surplus was led directly to the main condenser through the steam system dump line. This amount of heat represents a direct heat loss, because a high amount of produced steam can not be used anywhere in the steam propulsion system. As propulsion system load increases, steam system components (main and auxiliary) require more and more steam and at the middle steam system loads all produced steam will be used by system components, so from that moment on dump line is closed.

- Deaerator: Deaerator is a steam propulsion system component which has two important functions. First is feed water heating (the deaerator is open feed water heater) and the second is oxygen and other gases removal from feed water to avoid corrosion and cavitations in a feed water pipeline. For both of its functions deaerator requires auxiliary steam.

- Desuperheater: Desuperheater is used in the marine steam propulsion system to prepare auxiliary steam for additional heating purposes. In desuperheater, one small part of feed water is taken from the feed water pipeline and injected in auxiliary steam. On such way auxiliary steam temperature additionally decreases and steam is adequately prepared for additional heating purposes.

- Steam generators air heaters: Before entrance in each steam generator combustion chamber, air is heated in air heater. Heating medium is auxiliary steam. Each steam generator has one air heater. Air heaters are identical ones. Usually, in land-based steam power systems, air is heated with flue gases which exit from the steam gen- erator. In marine steam systems, flue gases temperature is not sufficient for air heating purposes, so air heating is obtained with auxiliary steam.

In analyzed marine steam propulsion system, it should be noted that only the splash steam system is constantly supplied with auxiliary steam flow from steam generators (from the lowest to the highest steam system load). Other auxiliary devices are supplied with steam from steam generators at low and middle steam system loads. At high steam system loads, auxiliary steam flow from steam generators significantly decreases, because the majority of auxiliary devices (all auxiliary devices except splash steam system) get a steam required for their operation from main steam turbine subtractions. This fact will be clearly seen from measurement results, Table 3 and Table 4.

\section{Equations for Energy Flow Streams Analysis}

\subsection{Energy Analysis - Governing Equations}

Energy analysis is defined by the first law of thermodynamics [24]. Mass and energy balance equations for a standard volume in steady state disregarding potential and kinetic energy are defined according to [25] and [26]:

$$
\begin{aligned}
& \Sigma \dot{m}_{I N}=\Sigma \dot{m}_{\text {OUT }} \\
& \dot{Q}-P=\Sigma \dot{m}_{\text {OUT }} \cdot h_{\text {OUT }}-\Sigma \dot{m}_{I N} \cdot h_{I N}
\end{aligned}
$$

Energy power of a flow for any fluid stream can be calculated according to [9] by using the equation:

$$
\dot{E}_{e n}=\dot{m} \cdot h
$$




\subsection{Calculation of Main and Auxiliary Energy Flow Streams from Marine Steam Generators}

Energy power of each steam flow stream (main and auxiliary) was calculated by using measured steam pressures, temperatures and mass flow rates, according to equation (3). Steam specific enthalpies were calculated from measured steam pressures and temperatures by using NIST REFPROP software [27].

Energy power values were presented for both steam generators throughout this paper, so it was investigated cumulative streams from the propulsion system. A steam flow stream which enters to each system device was produced by both steam generators, so only the cumulative flow streams can be relevant in energy analysis.

Auxiliary steam pressure and temperature (and consequentially auxiliary steam specific enthalpy) is not the same at the steam generator's outlet when compared to flow streams to each auxiliary device due to losses through the pipeline. On the other side, decrease in auxiliary steam pressure and temperature in the pipeline is small and in this paper is neglected. Auxiliary steam flow streams to each auxiliary device were calculated with the same specific enthalpy as at the steam generator's outlet, but with corresponding and measured steam mass flow rates.

Cumulative steam mass flow rate, which exits from both steam generators, is defined as:

$$
\dot{m}_{C U}=\dot{m}_{M A}+\dot{m}_{A U X}
$$

Cumulative steam energy power is:

$$
\dot{E}_{e n, C U}=\dot{E}_{e n, M A}+\dot{E}_{e n, A U X}
$$

where main and auxiliary steam energy power are defined as:

$$
\begin{aligned}
& \dot{E}_{e n, M A}=\dot{m}_{M A} \cdot h_{M A} \\
& \dot{E}_{e n, A U X}=\dot{m}_{A U X} \cdot h_{A U X}
\end{aligned}
$$

The share of main steam energy power in cumulative energy power is:

$$
S H_{M A}=\frac{\dot{E}_{e n, M A}}{\dot{E}_{e n, C U}} \cdot 100
$$

The share of auxiliary steam energy power in cumulative energy power is:

$$
S H_{A U X}=\frac{\dot{E}_{e n, A U X}}{\dot{E}_{e n, C U}} \cdot 100
$$

The auxiliary steam flow stream is divided on flow streams to each auxiliary device (auxiliary devices are splash steam system, dump line, deaerator, desuperheater and air heaters).

Mass flow rate balance for auxiliary steam flow stream is:

$$
\dot{m}_{A U X}=\dot{m}_{S S}+\dot{m}_{D U}+\dot{m}_{D E A}+\dot{m}_{D E S}+\dot{m}_{A H}
$$

As the change in auxiliary steam pressure and temperature through the pipeline is neglected, auxiliary steam energy power divided to each auxiliary device is:

$$
\begin{aligned}
& \dot{E}_{e n, A U X}=\dot{m}_{A U X} \cdot h_{A U X}= \\
& =\left(\dot{m}_{S S}+\dot{m}_{D U}+\dot{m}_{D E A}+\dot{m}_{D E S}+\dot{m}_{A H}\right) \cdot h_{A U X}
\end{aligned}
$$

Steam energy power to each auxiliary device is then:

$$
\dot{E}_{e n, A D}=\dot{m}_{A D} \cdot h_{A U X}
$$

The share of each auxiliary device energy power in the cumulative auxiliary energy power is:

$$
S H_{A D}=\frac{\dot{E}_{e n, A D}}{\dot{E}_{e n, A U X}} \cdot 100
$$

\section{Measurement Results of Main and Auxiliary Steam Flow Streams}

Measurements were performed in twenty four different LNG carrier steam system loads. Measurements of steam temperature, pressure and mass flow rate at each steam system load were obtained with measurement equipment already mounted on the steam system pipeline. That equipment is used for control and regulation of the entire steam system during LNG carrier exploitation.

The list of used measurement equipment is presented in Table 2.

Table 2 Used measurement equipment

\begin{tabular}{|l|c|}
\hline \multicolumn{2}{|c|}{ Main steam flow stream } \\
\hline Steam temperature & $\begin{array}{c}\text { Greisinger GTF 601-Pt100 - } \\
\text { immersion probe [28] }\end{array}$ \\
\hline Steam pressure & $\begin{array}{c}\text { Yamatake JTG980A - } \\
\text { pressure transmitter [29] }\end{array}$ \\
\hline $\begin{array}{l}\text { Steam mass flow } \\
\text { rate }\end{array}$ & $\begin{array}{c}\text { Yamatake JTD960A - } \\
\text { differential pressure transmitter [30] }\end{array}$ \\
\hline \multicolumn{2}{|c|}{ Auxiliary steam flow stream } \\
\hline Steam temperature & $\begin{array}{c}\text { Greisinger GTF 601-Pt100 - } \\
\text { immersion probe [28] }\end{array}$ \\
\hline Steam pressure & $\begin{array}{c}\text { Yamatake JTG980A - } \\
\text { pressure transmitter [29] }\end{array}$ \\
\hline $\begin{array}{l}\text { Steam mass flow } \\
\text { rate }\end{array}$ & $\begin{array}{r}\text { Yamatake JTD960A - } \\
\text { differential pressure transmitter [30] }\end{array}$ \\
\hline \multicolumn{2}{|c|}{ Auxiliary steam flow stream to each auxiliary device } \\
\hline $\begin{array}{l}\text { Steam mass flow } \\
\text { rate }\end{array}$ & $\begin{array}{c}\text { Yamatake JTD960A - } \\
\text { differential pressure transmitter [30] }\end{array}$ \\
\hline
\end{tabular}

All required steam operating parameters were presented in relation to propulsion propeller speed. Increase in propulsion propeller speed is directly proportional to increase in steam system load and vice versa.

Table 3 present measurement results of the main and cumulative auxiliary steam flow streams. Based on these data, it was performed calculation and comparison of steam energy power for each observed stream. 
Table 3 Measurement results for the main and cumulative auxiliary steam flow streams

\begin{tabular}{|c|c|c|c|c|c|c|}
\hline \multirow{2}{*}{$\begin{array}{c}\text { Propulsion } \\
\text { propeller speed } \\
\text { (rpm) }\end{array}$} & \multicolumn{3}{|c|}{ Main steam flow stream } & \multicolumn{3}{|c|}{ Auxiliary steam flow stream-cumulative } \\
\hline & $\begin{array}{c}\text { Steam } \\
\text { temperature }\left({ }^{\circ} \mathrm{C}\right)\end{array}$ & $\begin{array}{c}\text { Steam pressure } \\
(\mathrm{MPa})\end{array}$ & $\begin{array}{l}\text { Steam mass flow } \\
\text { rate }(\mathrm{kg} / \mathrm{h})\end{array}$ & $\begin{array}{c}\text { Steam } \\
\text { temperature }\left({ }^{\circ} \mathrm{C}\right)\end{array}$ & $\begin{array}{c}\text { Steam pressure } \\
(\mathrm{MPa})\end{array}$ & $\begin{array}{l}\text { Steam mass flow } \\
\text { rate }(\mathrm{kg} / \mathrm{h})\end{array}$ \\
\hline 25.00 & 501 & 6.20 & 16744 & 313 & 6.01 & 29876 \\
\hline 41.78 & 500 & 6.19 & 29394 & 304 & 6.11 & 17708 \\
\hline 53.50 & 509 & 6.10 & 47985 & 297 & 6.07 & 12170 \\
\hline 62.52 & 499 & 5.99 & 48977 & 299 & 5.95 & 14528 \\
\hline 63.55 & 500 & 5.99 & 52080 & 298 & 5.95 & 14915 \\
\hline 65.10 & 504 & 6.10 & 54438 & 299 & 6.10 & 15633 \\
\hline 66.08 & 515 & 6.08 & 56078 & 300 & 6.04 & 16133 \\
\hline 67.68 & 515 & 6.08 & 59201 & 301 & 6.04 & 16756 \\
\hline 73.09 & 515 & 6.10 & 70515 & 301 & 6.07 & 14690 \\
\hline 74.59 & 515 & 6.07 & 77211 & 299 & 6.04 & 10641 \\
\hline 76.56 & 515 & 6.07 & 82881 & 299 & 6.04 & 10848 \\
\hline 78.41 & 515 & 6.09 & 89907 & 299 & 6.06 & 10744 \\
\hline 79.46 & 498 & 5.94 & 95990 & 298 & 5.92 & 3273 \\
\hline 80.44 & 502 & 6.00 & 100540 & 297 & 5.94 & 3384 \\
\hline 81.49 & 500 & 5.99 & 102883 & 290 & 5.99 & 483 \\
\hline 82.88 & 501 & 5.99 & 108601 & 280 & 5.99 & 474 \\
\hline 83.00 & 501 & 5.99 & 109961 & 280 & 5.99 & 477 \\
\hline
\end{tabular}

Table 4 Auxiliary steam mass flow rates to each auxiliary device

\begin{tabular}{|c|c|c|c|c|c|c|c|}
\hline $\begin{array}{c}\text { Propulsion } \\
\text { propeller speed } \\
\text { (rpm) } \\
\end{array}$ & $\begin{array}{c}\text { Steam } \\
\text { temperature } \\
\left({ }^{\circ} \mathrm{C}\right) \\
\end{array}$ & $\begin{array}{l}\text { Steam } \\
\text { pressure } \\
(\mathrm{MPa}) \\
\end{array}$ & $\begin{array}{l}\text { Splash steam } \\
\text { mass flow } \\
\text { rate }(\mathrm{kg} / \mathrm{h}) \\
\end{array}$ & $\begin{array}{c}\text { Dump steam } \\
\text { mass flow rate } \\
(\mathrm{kg} / \mathrm{h}) \\
\end{array}$ & $\begin{array}{c}\text { Deaerator steam } \\
\text { mass flow rate } \\
(\mathrm{kg} / \mathrm{h})\end{array}$ & $\begin{array}{l}\text { Desuperheater } \\
\text { steam mass flow } \\
\text { rate }(\mathrm{kg} / \mathrm{h})\end{array}$ & $\begin{array}{c}\text { Air heaters steam } \\
\text { mass flow rate } \\
(\mathrm{kg} / \mathrm{h})\end{array}$ \\
\hline 25.00 & 313 & 6.01 & 428 & 15764 & 5881 & 3022 & 4781 \\
\hline 41.78 & 304 & 6.11 & 416 & 3696 & 6049 & 2687 & 4860 \\
\hline 53.50 & 297 & 6.07 & 442 & 0 & 3639 & 2792 & 5297 \\
\hline 56.65 & 297 & 5.94 & 475 & 0 & 8392 & 2796 & 5375 \\
\hline 62.52 & 299 & 5.95 & 470 & 0 & 5282 & 2903 & 5873 \\
\hline 63.55 & 298 & 5.95 & 478 & 0 & 5657 & 2677 & 6103 \\
\hline 65.10 & 299 & 6.10 & 470 & 0 & 6318 & 2587 & 6258 \\
\hline 66.08 & 300 & 6.04 & 489 & 0 & 6541 & 2690 & 6413 \\
\hline 67.68 & 301 & 6.04 & 494 & 0 & 6983 & 2797 & 6482 \\
\hline 73.09 & 301 & 6.07 & 494 & 0 & 4484 & 2584 & 7128 \\
\hline 74.59 & 299 & 6.04 & 491 & 0 & 0 & 2688 & 7462 \\
\hline 76.56 & 299 & 6.04 & 468 & 0 & 0 & 2793 & 7587 \\
\hline 78.41 & 299 & 6.06 & 472 & 0 & 0 & 2687 & 7585 \\
\hline 79.46 & 298 & 5.92 & 479 & 0 & 0 & 2794 & 0 \\
\hline 80.44 & 297 & 5.94 & 478 & 0 & 0 & 2906 & 0 \\
\hline 81.49 & 290 & 5.99 & 483 & 0 & 0 & 0 & 0 \\
\hline 82.88 & 280 & 5.99 & 474 & 0 & 0 & 0 & 0 \\
\hline 83.00 & 280 & 5.99 & 477 & 0 & 0 & 0 & 0 \\
\hline
\end{tabular}


Cumulative auxiliary steam flow stream is divided on flow streams to each auxiliary device. Losses of steam pressure and temperature in auxiliary steam pipeline are neglected (pressure and temperature of auxiliary steam are the same as at the steam generator's outlet), so for energy power calculation to each auxiliary device is needed only steam mass flow rates. Those steam mass flow rates are measured with the same control and regulation measuring equipment as before and presented in Table 4 .

\section{Results of Main and Auxiliary Steam Flow Streams Energy Analysis with Discussion}

As declared before, the auxiliary steam flow stream is produced from the main flow stream. One part of produced main steam stream, which was not led to steam turbines, was sent back to steam generators where passing through steam drums and transferred a part of its heat content to feed water. In such way, the auxiliary steam temperature significantly decreases.
The temperature difference change between main and auxiliary steam flow streams during the increase in steam system load can be seen in Fig. 2. That temperature difference continuously increases during the increase in steam system load from $188{ }^{\circ} \mathrm{C}$ at propulsion propeller speed of $25.00 \mathrm{rpm}$ up to $221^{\circ} \mathrm{C}$ at propulsion propeller speed of $83.00 \mathrm{rpm}$. In the whole range of observed steam system loads auxiliary steam flow stream, when compared to main steam flow stream, has lower temperature for $208.4{ }^{\circ} \mathrm{C}$ on average.

Auxiliary steam flow stream pressure also decreases when compared to main steam flow stream, but that decrease is not as significant as decrease in temperature, Fig. 3. The highest pressure differences between main and auxiliary steam flow streams can be seen at the lowest steam system loads (between $25.00 \mathrm{rpm}$ and $41.78 \mathrm{rpm}$ ). When compared to main steam flow stream, the auxiliary flow stream has lower pressure for $0.0425 \mathrm{MPa}$ on average throughout the whole range of observed steam system loads.

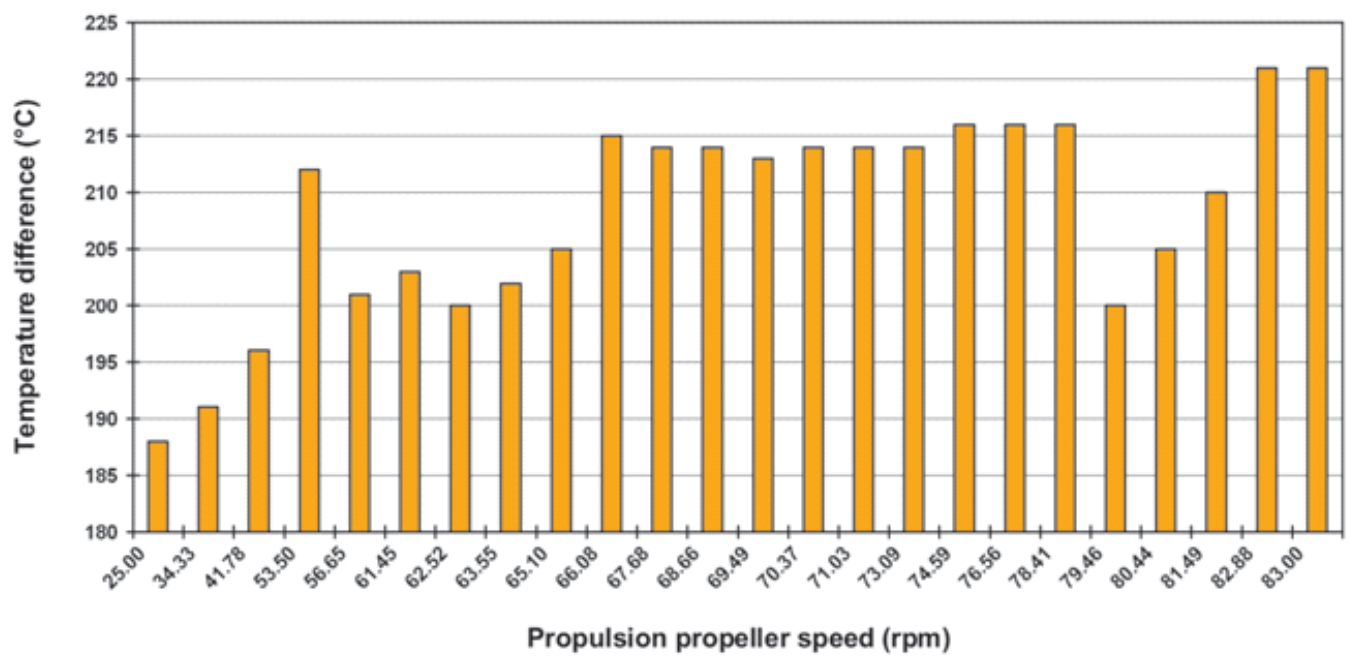

Figure 2 Temperature difference change between main and auxiliary steam flow streams

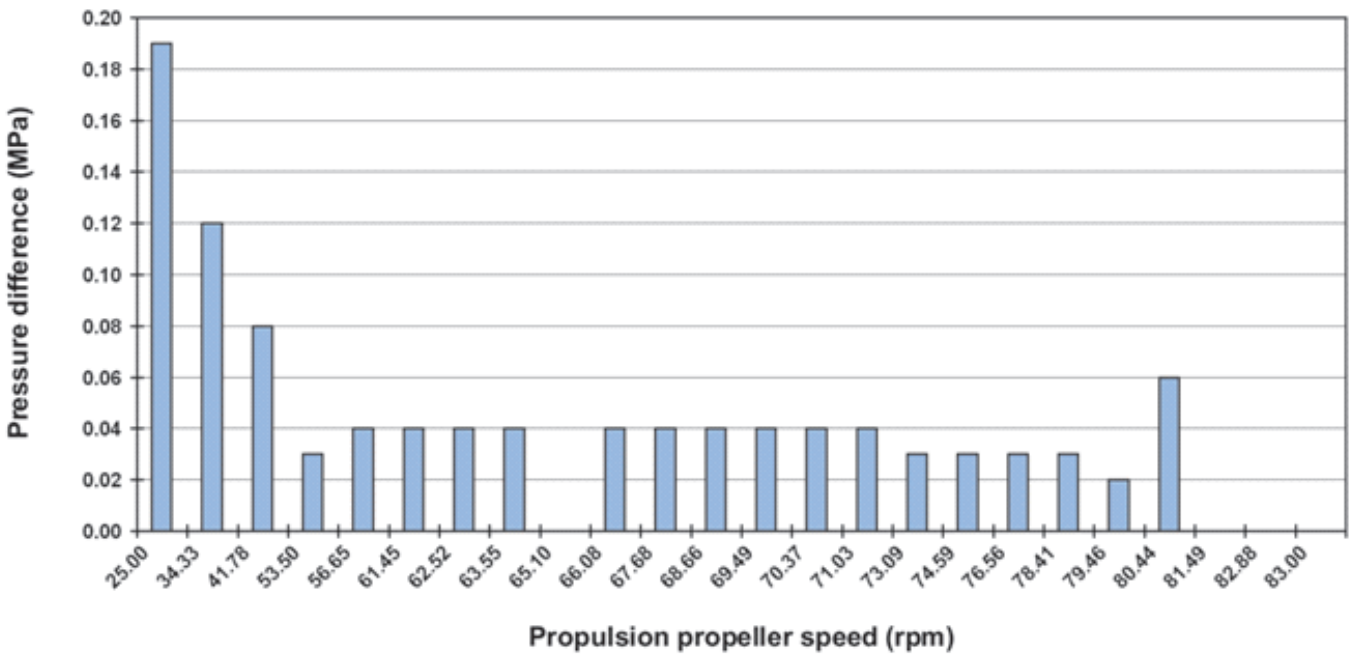

Figure 3 Pressure difference change between main and auxiliary steam flow streams 
At the highest steam system loads (between propulsion propeller speeds of $81.49 \mathrm{rpm}$ and $83.00 \mathrm{rpm}$ ) main and auxiliary steam flow streams has the same pressure, Fig. 3. From this observation can be concluded that the main reason of producing an auxiliary steam flow stream is to reduce its temperature and to properly use it in auxiliary system devices. The main steam flow stream cannot be used for any auxiliary device operation because such high temperatures can cause serious damage of auxiliary devices.

Auxiliary steam flow stream production transferred a certain amount of heat to feed water in steam drums. From that feed water will be produced main steam flow stream. In such way, production of auxiliary steam flow stream also reduces steam generators fuel consumption.

Change in energy power of main and auxiliary steam flow streams is presented in Fig. 4. Energy power of the auxiliary flow stream is higher than energy power of the main flow stream at the lowest two steam system loads. Increase in steam system load (increase in propulsion pro- peller speed) resulted with continuous increase in energy power of the main steam flow stream, while at the same time energy power of the auxiliary steam flow stream continuously decreases. At the highest observed steam system load $(83.00 \mathrm{rpm})$ energy power of the main steam flow stream amounts $104634 \mathrm{~kW}$, while at the same load energy power of the auxiliary steam flow stream amounts only $371.7 \mathrm{~kW}$.

Continuous decrease in energy power of the auxiliary steam flow stream during increase in steam system load does not mean that auxiliary devices use less and less steam as the system load increases. Deaerator, desuperheater and air heaters take auxiliary steam from steam generators until certain system loads after which they are supplied with steam from main steam turbine subtractions. Only the splash steam system is constantly supplied with an auxiliary steam flow stream from steam generators.

Increase in steam system load resulted with an increase in steam consumption of auxiliary devices. Steam

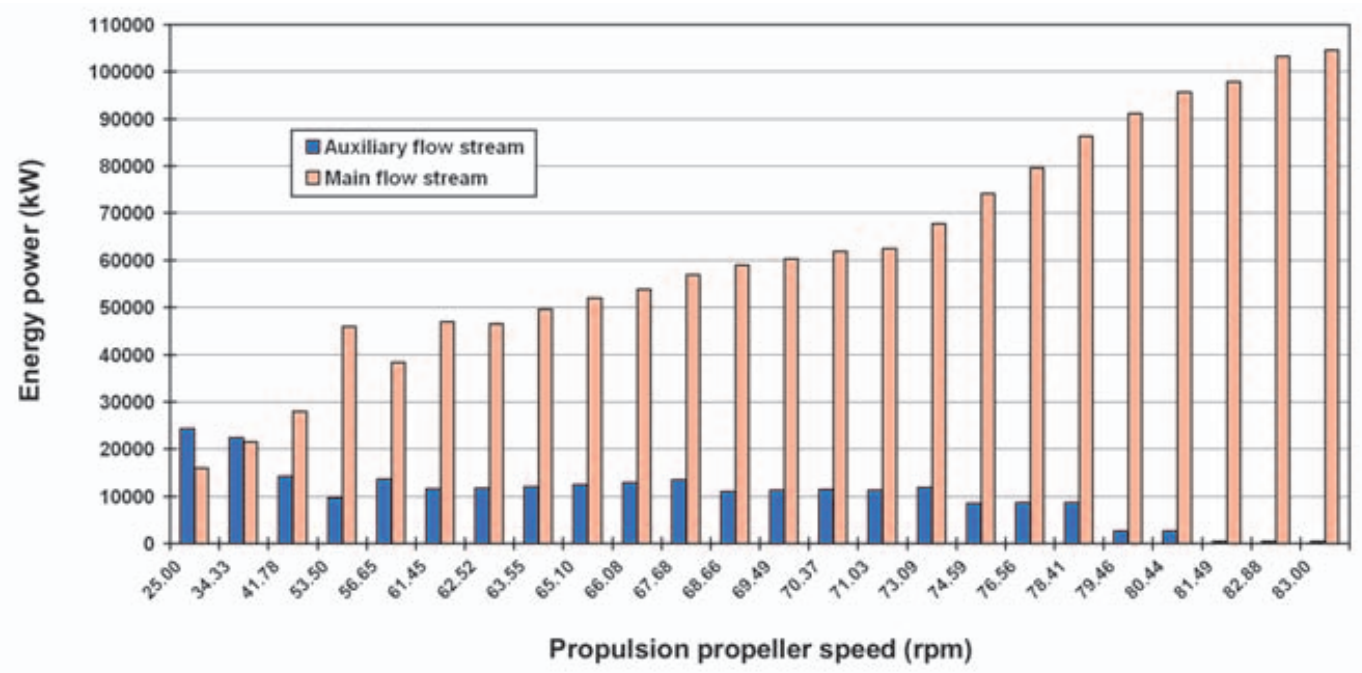

Figure 4 Change in energy power of main and auxiliary steam flow streams

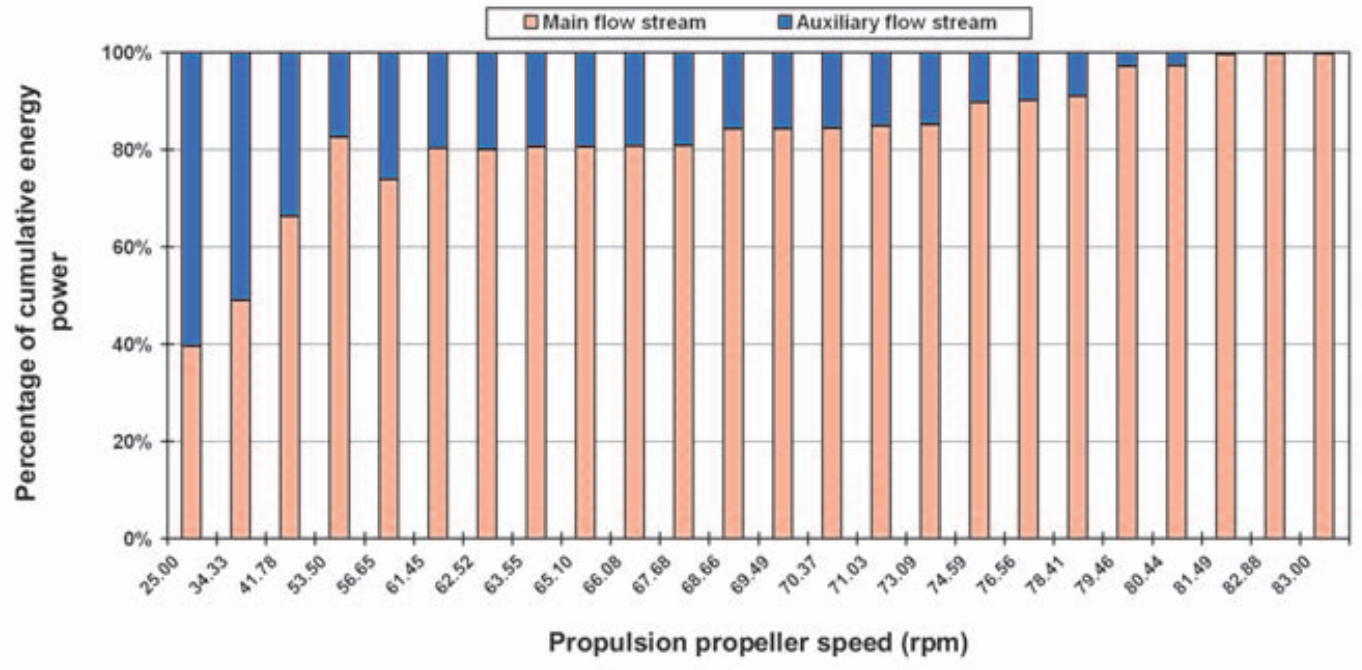

Figure 5 Energy power of main and auxiliary steam flow streams share in cumulative energy power 
for auxiliary devices operation is obtained from steam generators (auxiliary steam flow stream) at low and middle system loads, while the majority of auxiliary devices gets steam from main steam turbine subtractions at high system loads.

Energy power of main and auxiliary steam flow streams, equation (5), represents cumulative energy power. As can be seen from Fig. 5, auxiliary flow stream energy power has a higher share in cumulative energy power only at $25.00 \mathrm{rpm}(60.43 \%)$ and at $34.33 \mathrm{rpm}(50.98 \%)$. Increase in steam system load reduces a share of auxiliary flow stream energy power in cumulative energy power. At middle steam system loads (between $53.50 \mathrm{rpm}$ and 67.68 rpm) energy power of the auxiliary flow stream takes share around $20 \%$ in cumulative energy power. At the highest observed steam system loads (from $81.49 \mathrm{rpm}$ to $83.00 \mathrm{rpm}$ ) energy power of the main steam flow stream takes a share in cumulative energy power of $99.60 \%$.

Energy power of the auxiliary steam flow stream produced in steam generators was led to each auxiliary device. Due to different scales, energy power to each auxiliary device must be divided according to steam system loads on low loads, Fig. 6 and middle/high loads, Fig. 7.

At low steam system loads, between $25.00 \mathrm{rpm}$ and $41.78 \mathrm{rpm}$, Fig. 6, the highest amount of auxiliary steam flow stream energy power was irretrievably lost because it is not needed in the steam system - so it passes through the dump line. As system load increases, energy power sent to the dump line decreases, and after $41.78 \mathrm{rpm}$ dump line is closed. Deaerator is the second consumer of auxiliary steam energy power at low system loads (deaerator uses energy power of $4963 \mathrm{~kW}$ on average at low loads), after which follows air heaters and desuperheater. A splash steam system at low system loads takes the lowest amount of auxiliary steam flow stream energy power, much lower than the other auxiliary devices, Fig. 6.

The largest consumers of auxiliary steam flow stream energy power at the middle and high steam system loads are deaerator and air heaters, Fig. 7. Air heaters at middle and high system loads uses auxiliary flow stream energy

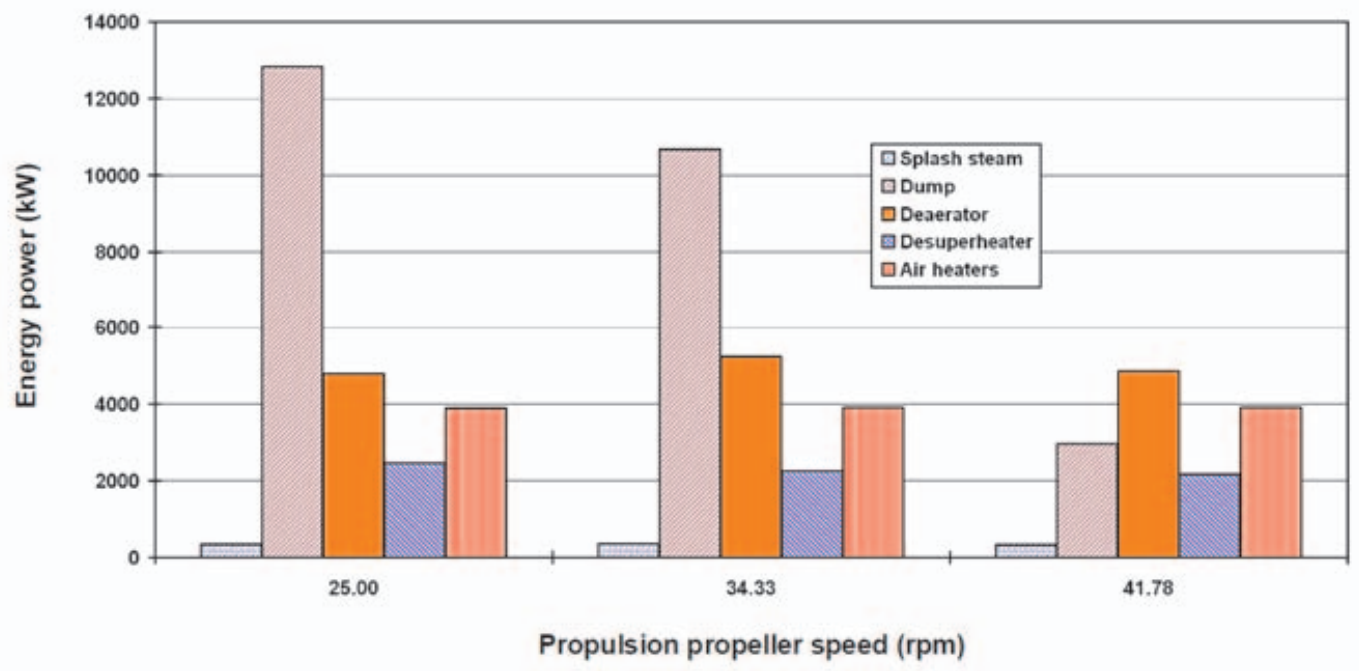

Figure 6 Steam energy power to each auxiliary device - low propulsion propeller speeds

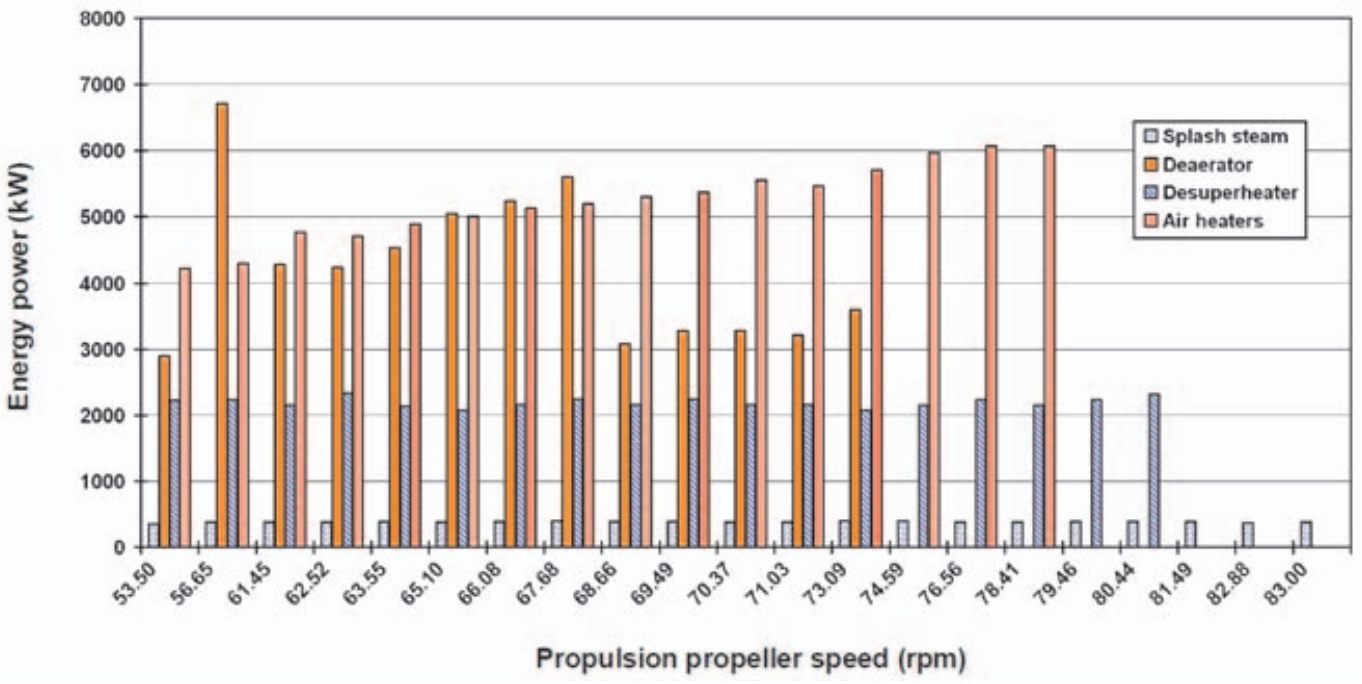

Figure 7 Steam energy power to each auxiliary device - middle and high propulsion propeller speeds 
power of $5240 \mathrm{~kW}$ on average. At $79.46 \mathrm{rpm}$, air heaters steam supply was not anymore from steam generators but from the main turbine subtraction.

The deaerator uses energy power of $4900 \mathrm{~kW}$ on average from $53.50 \mathrm{rpm}$ to $67.68 \mathrm{rpm}$. At $68.66 \mathrm{rpm}$, the auxiliary steam flow stream which was led to deaerator significantly decreases because from that moment on steam was led to deaerator simultaneously from steam generators (auxiliary stream flow) and from the main turbine subtraction. At propulsion propeller speed of 74.59 rpm, deaerator gets steam for its operation only from the main turbine subtraction.

Throughout the entire time of its operation while using an auxiliary steam flow stream, desuperheater uses approximately $2200 \mathrm{~kW}$ of auxiliary steam energy power. At three highest observed system loads (81.49 rpm, $82.88 \mathrm{rpm}$ and $83.00 \mathrm{rpm}$ ), desuperheater gets a steam from the main turbine subtraction, as deaerator and air heaters.
The splash steam system is the only auxiliary device which operates with auxiliary steam flow stream produced in the steam generators during entire period of steam system operation, at any loads, Fig. 6 and Fig 7. Splash steam system uses a small amount of auxiliary flow stream energy power which amounts $377 \mathrm{~kW}$ on average for the entire range of observed propulsion propeller speeds (from $25.00 \mathrm{rpm}$ to $83.00 \mathrm{rpm}$ ).

In Fig. 8 and Fig. 9 is presented share of each auxiliary device in cumulative auxiliary energy power produced in steam generators. As before, it was necessary to present share of each auxiliary device in cumulative auxiliary energy power at low system loads, Fig. 8 and at middle/high system loads, Fig. 9 due to different scales.

At low propulsion propeller speeds (at low steam system loads) share of dump line in cumulative auxiliary energy power decreases during the load increase from $52.76 \%$ at $25.00 \mathrm{rpm}$ to $47.56 \%$ at $34.33 \mathrm{rpm}$ and finally to $20.87 \%$ at $41.78 \mathrm{rpm}$, Fig. 8. Between the same

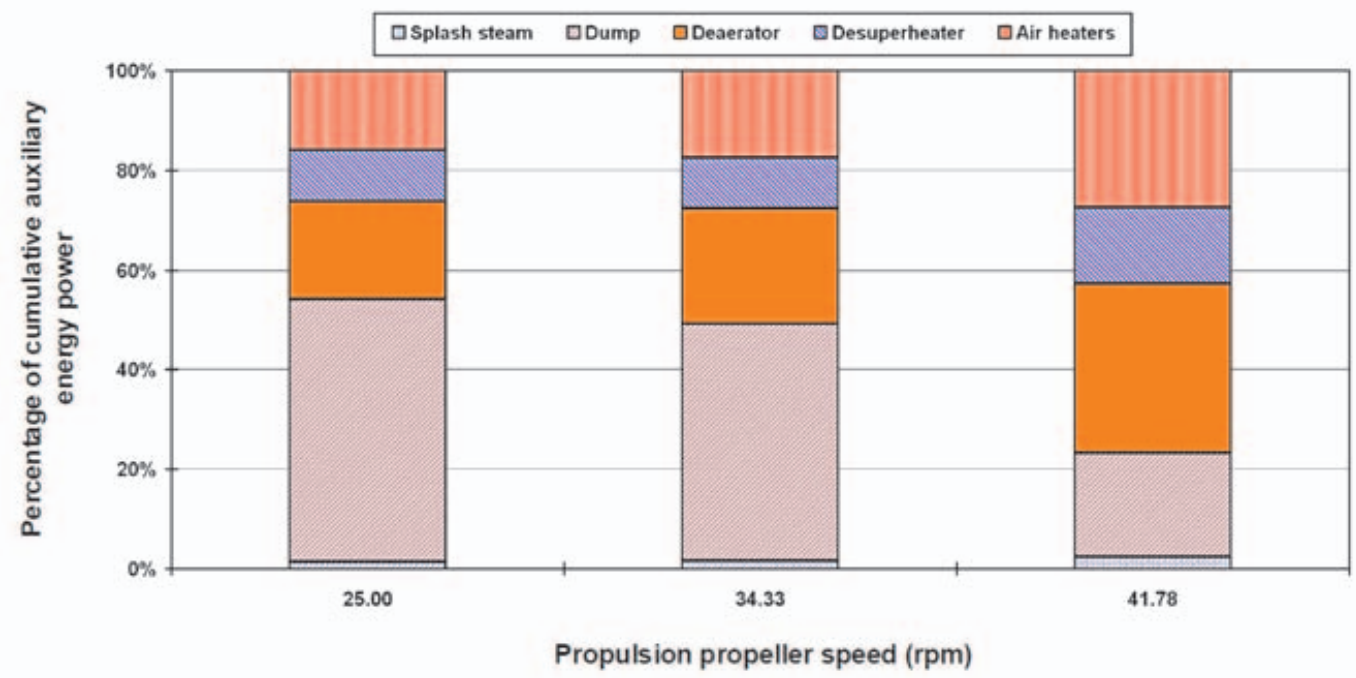

Figure 8 Share in the cumulative auxiliary energy power of each auxiliary device - low propulsion propeller speeds

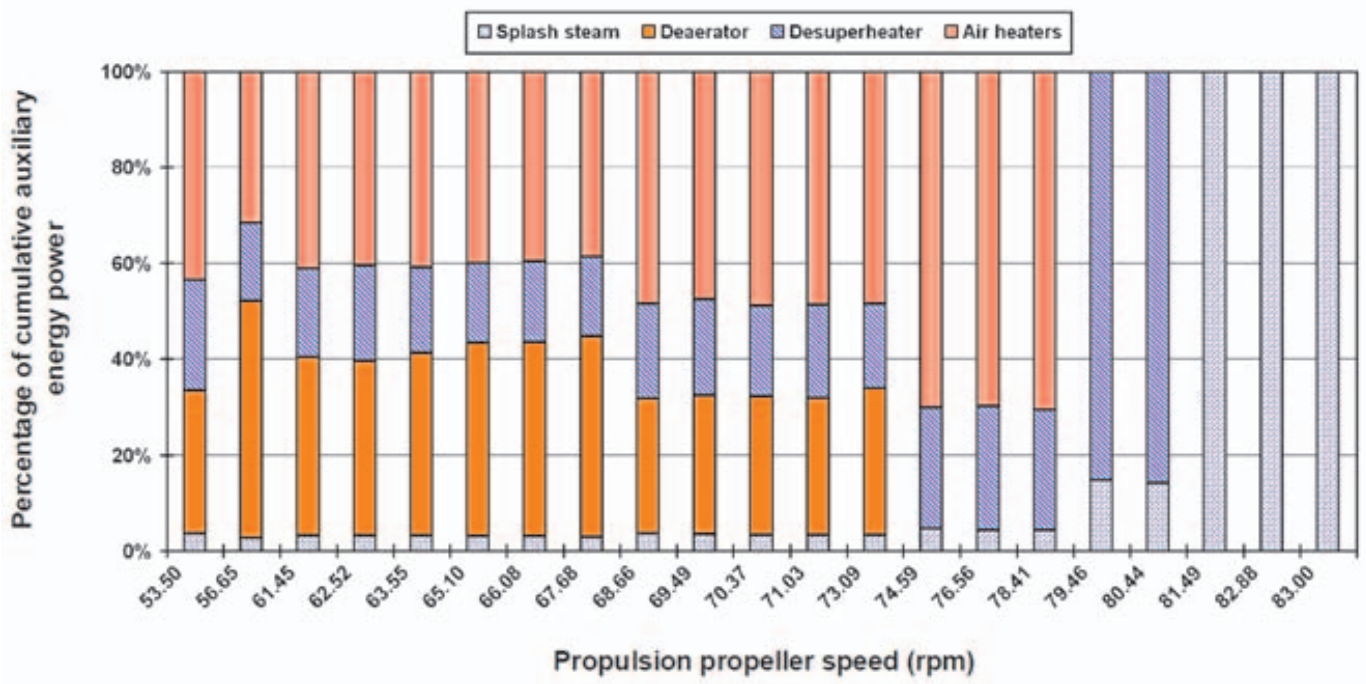

Figure 9 Share in the cumulative auxiliary energy power of each auxiliary device - middle and high propulsion propeller speeds 
propulsion propeller speeds share of deaerator and air heaters in cumulative auxiliary energy power increases (from $19.68 \%-25.00 \mathrm{rpm}$ to $34.16 \%-41.78 \mathrm{rpm}$ for deaerator and from $16.00 \%-25.00 \mathrm{rpm}$ to $27.45 \%$ $41.78 \mathrm{rpm}$ for air heaters). Increase in system load resulted also with the increase of the desuperheater share in cumulative auxiliary energy power from $10.10 \%$ at $34.33 \mathrm{rpm}$ to $15.17 \%$ at $41.78 \mathrm{rpm}$. Splash steam system share in cumulative auxiliary energy power also increases during the increase in steam system load, but that increase is lower than $1 \%$ at observed low propulsion propeller speeds.

At middle and high propulsion propeller speeds dump line is closed, so share in cumulative auxiliary energy power produced in steam generators takes another four auxiliary devices, Fig. 9.

Until $68.66 \mathrm{rpm}$, deaerator uses the share of approximately $37 \%$ in cumulative auxiliary energy power, while the average shares of other auxiliary devices are: air heaters $-41 \%$, desuperheater $-18 \%$ and splash steam system $-3 \%$.

Between $68.66 \mathrm{rpm}$ and $73.09 \mathrm{rpm}$, deaerator uses a steam flow simultaneously from steam generators (auxiliary steam) and from main steam turbine subtraction, so its share in cumulative auxiliary energy power decreases on approximately $29 \%$. At the same time, share of air heaters increase to $49 \%$ on average and share of desuperheater increases to $19 \%$ on average. Splash steam system share in cumulative auxiliary energy power also increases between $68.66 \mathrm{rpm}$ and $73.09 \mathrm{rpm}$, but the increase is almost negligible.

From $74.59 \mathrm{rpm}$ on, deaerator uses a steam flow only from main steam turbine subtraction, so between 74.59 rpm and $78.41 \mathrm{rpm}$ air heaters takes the highest share in cumulative auxiliary energy power which amounts around $70 \%$, desuperheater takes a share of $25 \%$ and splash steam system share is around $5 \%$.

From $79.46 \mathrm{rpm}$ on, air heaters takes a steam flow only from main steam turbine subtraction. At $79.46 \mathrm{rpm}$ and $80.44 \mathrm{rpm}$ only two auxiliary steam flow consumers are desuperheater and splash steam system, which takes a share in cumulative auxiliary energy power of $85 \%$ - desuperheater and $15 \%$ - splash steam system.

At three highest steam system loads only auxiliary device which operates with auxiliary steam produced in steam generators is a splash steam system, Fig. 9.

\section{Conclusion}

This paper analyzes changes in main and auxiliary energy steam flow streams from steam generators during the increase in steam system load at conventional LNG carrier. Differences in steam pressure and temperature between main and auxiliary steam energy flow streams were compared and analyzed during the all specter of system loads. Energy power of main and auxiliary steam flow streams was compared and its share in cumulative energy power produced in steam generators was presented. Energy flow stream consumption of each auxiliary device was also investigated and it is presented share of each auxiliary device in cumulative auxiliary energy power at all observed steam system loads. The main conclusions obtained from the analysis are:

- Marine steam generators simultaneously produced main and auxiliary steam flow streams, regardless of steam system load,

- Main steam flow stream has significantly higher temperature and just little higher pressure when compared to auxiliary steam flow stream,

- Auxiliary flow stream is used for the operation of auxiliary devices in steam system,

- Energy power of the auxiliary steam flow stream is higher than energy power of the main steam flow stream only at the lowest steam system loads,

- Energy power of cumulative auxiliary flow stream decreases during the increase in steam system load,

- Auxiliary devices use an auxiliary steam flow stream from steam generators until the opening of steam subtractions from the main turbine (with an exception of deaerator),

- Dump line is the highest consumer of the auxiliary steam flow stream at the lowest system loads. A steam flow stream which passes through the dump line represent a direct heat loss of the system,

- The splash steam system is the only auxiliary device which continuously uses auxiliary steam flow stream produced in the steam generators throughout the entire steam system operation period.

\section{Acknowledgment}

The authors would like to extend their appreciations to the main ship-owner office for conceding measuring equipment and for all help during the exploitation measurements. This work was supported by the University of Rijeka - contract no. 13.09.1.1.05 and Croatian Science Foundation-project 8722.

\section{References}

[1] Zhao, F., Yang, W., Tan, W. W., Yu, W., Yang, J., Chou, S. K.: Power management of vessel propulsion system for thrust efficiency and emissions mitigation, Applied Energy 161, pp. 124-132, 2016. (doi: 10.1016/j.apenergy.2015.10.022)

[2] Senčić, T., Račić, N., Franković, B.: Influence of Low-Speed Marine Diesel Engine Settings on Waste Heat Availability, Shipbuilding: Theory and Practice of Naval Architecture, Marine Engineering and Ocean Engineering Vol. 63, No. 4, pp. 329-335, 2012. (UDC 621.436:629.5)

[3] Mrzljak, V., Medica, V., Bukovac, O.: Simulation of a two-stroke slow speed diesel engine using a quasi-dimensional model, Transactions of FAMENA Vol. 40, No. 2, pp. 35-44, 2016. (doi: 10.21278/TOF.40203)

[4] Mrzljak, V., Medica, V., Bukovac, O.: Volume agglomeration process in quasi-dimensional direct injection diesel engine numerical model, Energy 115, pp. 658-667, 2016. (doi: 10.1016/j.energy.2016.09.055) 
[5] Bukovac, O., Medica, V., Mrzljak, V.: Steady state performances analysis of modern marine two-stroke low speed diesel engine using MLP neural network model, Shipbuilding: Theory and Practice of Naval Architecture, Marine Engineering and Ocean Engineering Vol. 66, No. 4, pp. 57-70, 2015. (UDC 629.54:621.436.13:519.6)

[6] Attah, E. E., Bucknall, R.: An analysis of the energy efficiency of LNG ships powering options using the EEDI, Ocean Engineering 110, Part B, pp. 62-74, 2015. (doi: 10.1016/j. oceaneng.2015.09.040)

[7] Fernández, I. A., Gómez, M. R., Gómez, J. R., Insua, A. A. B.: Review of propulsion systems on LNG carriers, Renewable and Sustainable Energy Reviews 67, pp. 1395-1411, 2017. (doi: 10.1016/j.rser.2016.09.095)

[8] Mrzljak, V., Poljak, I., Medica-Viola, V.: Dual fuel consumption and efficiency of marine steam generators for the propulsion of LNG carrier, Applied Thermal Engineering, 119, pp. 331346, 2017. (doi: 10.1016/j.applthermaleng.2017.03.078)

[9] Mrzljak, V., Poljak, I., Mrakovčić, T.: Energy and exergy analysis of the turbo-generators and steam turbine for the main feed water pump drive on LNG carrier, Energy Conversion and Management, 140, pp. 307-323, 2017. (doi: 10.1016/j. enconman.2017.03.007)

[10] Taylor, D. A.: Introduction to Marine Engineering, Elsevier Butterworth-Heinemann, 1998.

[11] Medica-Viola, V., Pavković, B., Mrzljak, V.: Numerical model for on-condition monitoring of condenser in coal-fired power plants, International Journal of Heat and Mass Transfer 117, pp. 912-923, 2018. (doi: 10.1016/j.ijheatmasstransfer.2017.10.047)

[12] Baawain, M., Choudri, B. S., Ahmed, M., Purnama, A.: Recent Progress in Desalination, Environmental and Marine Outfall Systems, Springer International Publishing Switzerland, 2015. (doi: 10.1007/978-3-319-19123-2)

[13] Mrzljak, V., Poljak, I., Medica-Viola, V.: Energy and Exergy Efficiency Analysis of Sealing Steam Condenser in Propulsion System of LNG Carrier, Our Sea, International Journal of Maritime Science \& Technology, Vol. 64, No. 1, pp. 20-25, 2017. (doi: 10.17818/NM/2017/1.4)

[14] Mrzljak, V., Poljak, I., Medica-Viola, V.: Efficiency and losses analysis of low-pressure feed water heater in steam propulsion system during ship maneuvering period, Scientific Journal of Maritime Research Vol. 30, No. 2, pp. 133-140, 2016.

[15] Mrzljak, V., Poljak, I., Medica-Viola, V.: Thermodynamical analysis of high-pressure fed water heater in steam propulsion system during exploitation, Shipbuilding: Theory and Practice of Naval Architecture, Marine Engineering and Ocean Engineering, Vol. 68, No. 2, pp. 45-61, 2017. (doi: $10.21278 /$ brod68204)
[16] Moran M., Shapiro H., Boettner, D. D., Bailey, M. B.: Fundamentals of engineering thermodynamics, Seventh edition, John Wiley and Sons, Inc., 2011.

[17] Cengel Y., Boles M.: Thermodynamics an engineering approach, Eighth edition, McGraw-Hill Education, 2015.

[18] Sutton, I.: Plant Design and Operations, Elsevier Inc., 2015.

[19] Chang, D., Rhee, T., Nam, K., Chang, K., Lee, D., Jeong, S.: A study on availability and safety of new propulsion systems for LNG carriers, Reliability Engineering and System Safety 93, pp. 1877-1885, 2008. (doi: 10.1016/j.ress.2008.03.013)

[20] Schinas, O., Butler, M.: Feasibility and commercial considerations of LNG-fueled ships, Ocean Engineering, 122, pp. 84-96, 2016. (doi: 10.1016/j.oceaneng.2016.04.031)

[21] Senary, K., Tawfik, A., Hegazy, E., Ali, A.: Development of a waste heat recovery system onboard LNG carrier to meet IMO regulations, Alexandria Engineering Journal 55, Issue 3, pp. 1951-1960, 2016. (doi: 10.1016/j.aej.2016.07.027)

[22] Raj, R., Ghandehariun, S., Kumar, A., Geng, J., Ma, L.: $A$ techno-economic study of shipping LNG to the Asia-Pacific from Western Canada by LNG carrier, Journal of Natural Gas Science and Engineering 34, pp. 979-992, 2016. (doi: 10.1016/j.jngse.2016.07.024)

[23] Vanem, E., Antao, P., Østvik, I., Del Castillo de Comas, F.: Analysing the risk of $L N G$ carrier operations, Reliability Engineering and System Safety 93, pp. 1328-1344, 2008. (doi: 10.1016/j.ress.2007.07.007)

[24] Kaushik, S. C., Siva Reddy, V., Tyagi, S. K.: Energy and exergy analyses of thermal power plants: A review, Renewable and Sustainable Energy Reviews 15, pp. 1857-1872, 2011. (doi: 10.1016/j.rser.2010.12.007)

[25] Hafdhi, F., Khir, T., Ben Yahyia, A., Ben Brahim, A.: Energetic and exergetic analysis of a steam turbine power plant in an existing phosphoric acid factory, Energy Conversion and Management 106, p. 1230-1241, 2015. (doi: 10.1016/j.enconman.2015.10.044)

[26] Erdem, H.H., Akkaya, A.V., Cetin, B., Dagdas, A., Sevilgen, S.H., Sahin, B., Teke, I., Gungor, C., Atas, S.: Comparative energetic and exergetic performance analyses for coal-fired thermal power plants in Turkey, International Journal of Thermal Sciences, 48, pp. 2179-2186, 2009. (doi: 10.1016/j.ijthermalsci.2009.03.007)

[27] Lemmon, E. W., Huber, M. L., McLinden, M. O.: NIST Reference Fluid Thermodynamic and Transport Properties-REFPROP, Version 8.0, User's Guide, Colorado, 2007.

[28] https://www.greisinger.de (accessed: 22.02.2018)

[29] http://www.industriascontrolpro.com (accessed: 19.02. 2018)

[30] http://www.krtproduct.com (accessed: 18.02.2018) 